\title{
DRUŠTVENI UTJECAJ NARODNIH KNJIŽNICA TIJEKOM PANDEMIJE COVID-19 U KONTEKSTU KONCEPTA PAMETNIH GRADOVA - KOMPARACIJA SINGAPURA I HRVATSKE
}

\author{
SOCIAL IMPACT OF PUBLIC LIBRARIES \\ DURING THE COVID-19 PANDEMIC IN THE CONTEXT \\ OF THE SMART CITIES CONCEPT - A COMPARISON \\ OF SINGAPORE AND CROATIA
}

Dijana Sabolović-Krajina

Knjižnica i čitaonica „Fran Galovićc“ Koprivnica

dijana@knjiznica-koprivnica.hr

\author{
UDK / UDC [027.022: 004.738.5]:616.2- \\ $044.372(592.3: 497.5)$ \\ Stručni rad / Professional paper \\ Primljeno / Received: 24. 12. 2020. \\ Prihvaćeno / Accepted: 8. 3. 2021.
}

\section{Sažetak}

Cilj/svrha. Cilj je ukazati na društveni utjecaj narodnih knjižnica u kriznoj situaciji suočavanja s pandemijom bolesti COVID-19, a u kontekstu njihove pozicije u suvremenom gospodarsko-razvojnom i političko-upravljačkom konceptu pametnih gradova čije je polazište da su informacije, znanje, digitalizacija i tehnologija (intelektualni kapital) pokretači gospodarstva i cjelokupnog društvenog razvoja.

Pristup/metodologija. Koristit će se metoda benchmarking ili usporedbe hrvatske prakse, u kojoj knjižnice uglavnom nisu prepoznate kao dio koncepta i strategija pametnih gradova, s praksom knjižnica u Singapuru koje prednjače u svijetu po svojoj uključenosti u nacionalnu strategiju pametne nacije. Analizom objava na društvenim mrežama uspoređuju se poslovne strategije kojima su se singapurske i odabrane hrvatske narodne knjižnice služile u odnosima s javnošću tijekom prvog vala pandemije bolesti COVID-19 u prvoj polovici 2020. godine. Nastoji se dobiti uvid u načine zadržavanja

Vjesnik bibliotekara Hrvatske 64, 1(2021), 209-226 ISSN 0507-1925 
društvenog utjecaja knjižnica tijekom zatvaranja knjižničnih zgrada za korisnike i nastojanja da u digitalnom ili elektroničkom obliku obavljaju vitalne informacijske, obrazovne, kulturne i socijalne uloge i zadaće koje definiraju njihov položaj u suvremenom društvu. Predmet su usporedbe objave na Twitteru narodnih knjižnica u Singapuru te na Facebooku dviju narodnih knjižnica u Hrvatskoj koje djeluju u tzv. vodećim hrvatskim pametnim gradovima - Gradske knjižnice Rijeka i Knjižnice i čitaonice „Fran Galović“ Koprivnica.

Rezultati. Rad će rezultirati novim spoznajama o djelovanju knjižnica u kriznim situacijama u zemlji i inozemstvu s obzirom na povezanost njihove prakse s pozicijom u strateško-razvojnim konceptima i planovima sredina u kojima djeluju.

Praktična primjena. Uvid u djelovanje knjižnica tijekom pandemije bolesti COVID-19 prilog je razmatranju praksi knjižnica u kriznoj situaciji s jedne strane, a podloga za poboljšanje planiranja upravljanja krizom u hrvatskim knjižnicama kako na nacionalnoj razini tako i u lokalnim sredinama.

Originalnost/vrijednost. Ovim se radom prvi put $u$ hrvatskom knjižničarskom diskursu analizira značaj knjižnica u kriznoj situaciji s obzirom na njihovu poziciju u konceptu i strategiji pametnih gradova / pametnih društava / pametnih nacija.

Ključne riječi: društveni utjecaj knjižnica; Hrvatska; narodne knjižnice; pametne nacije; pametni gradovi; pandemija bolesti COVID-19; Singapur; upravljanje krizom

\section{Abstract}

Aim/purpose. The aim of the paper is to point out the social impact of public libraries in the crisis situation caused by the COVID-19 disease pandemic in the context of their position within the contemporary concept of smart cities, whose starting point is that information, knowledge, digitalization and technology (intellectual capital) are drivers of the economy and overall social development.

Approach/methodology. The benchmarking method is used. The Croatian practice in which libraries are, for the most part, not yet recognized as an integral part of the concept and strategy of smart cities has been compared with the library practice in Singapore, the world leader in libraries' involvement in the national strategy of a smart nation. The analysis of social media posts compares the business strategies used by the Singapore's and Croatian public libraries in public relations during the first wave of the COVID-19 disease pandemic in the first half of 2020. Their goal was to maintain the social impact of libraries after the closure of physical spaces during quarantine (lockdown) in order to continue to perform informational, educational, cultural and social roles and tasks in digital or electronic form. The subject of the comparison is the posting on Twitter from February to September 2020 in the case of libraries in Singapore, and two public libraries in Croatia on Facebook from March to September 2020. The two Croatian libraries operate in the two leading Croatian smart cities - in the category of 
large Croatian cities it is The Rijeka City Library, and the category of medium-sized Croatian cities it is The Fran Galović Public Library in Koprivnica.

The results. The paper results provide new insights into the business operation of libraries in crisis situations in Croatia and abroad with regard to their place in the strategic-developmental and political-management concepts of their countries and communities.

Practical implications. An insight into the activities of libraries during the COVID-19 disease pandemic is a contribution to the consideration of library practices in a crisis situation on the one hand, and a basis for planning systematic crisis management in Croatian libraries both nationally and locally.

Originality/value. This paper, for the first time in Croatian library discourse, analyzes the importance of libraries in a crisis situation, and their position in the economic-developmental and political-management concept of smart cities / smart societies / smart nations.

Keywords: the COVID-19 disease pandemic; crisis management; Croatia; public libraries; Singapore; smart cities; smart nations; social impact of libraries

\section{Uvod}

Cilj je rada ukazati na pojedine aspekte organiziranja, poslovanja i djelovanja knjižnica u kriznim uvjetima, konkretno u suočavanju s globalnom zdravstvenom i društvenom krizom izazvanom nekontroliranim širenjem koronavirusa (SARSCoV-2) koji uzrokuje bolest COVID-19. U svega nekoliko mjeseci, od kraja 2019. i tijekom 2020. godine, ta je ugroza pogodila sve segmente života u cijelom svijetu, pa tako i u Hrvatskoj. ${ }^{1}$

Radom se želi utvrditi utječe li pozicija knjižnica u suvremenom razvojno-gospodarskom i političko-upravljačkom konceptu i strategijama pametnih gradova / pametnih društava ${ }^{2}$ / pametnih nacija na njihovo snalaženje i zadržavanje društvenog utjecaja u pandemiji bolesti COVID-19. U radu se polazi od toga da se u

\footnotetext{
1 Mikac, R. Kako Hrvatska upravlja krizama u kojima se našla? // Politička misao (31. 3. 2020.). [citirano: 2020-12-20]. Dostupno na: http://politickamisao.com/kako-hrvatska-upravlja-krizama-u-kojima-se-nasla/

2 Uloga knjižnica i knjižničara u globalnoj digitalnoj transformaciji za pametne gradove bila je tema međunarodne satelitske IFLA-ine konferencije koja je održana u Zagrebu 20. - 21. kolovoza 2019. pod nazivom Librarians and information professionals as (pro)motors of change: immersing, including and initiating digital transformation for smart societies. Više od 200 sudionika raspravljalo je o utjecaju digitalnog svijeta na sadašnje i buduće radne vještine knjižničara te ulozi knjižnica u digitalnoj transformaciji i razvoju pametnih društava. Usp. IFLA CPDWL Satellite Meeting 2019, Zagreb, Croatia, 20 - 21 August 2019. [citirano: 2020-12-20]. Dostupno na: https://ifla.hkdrustvo.hr/.
} 
drugom desetljeću 21. stoljeća mnoge knjižnice u svijetu, ponajprije u zemljama s razvijenim gospodarstvima i dugom demokratskom tradicijom, pozicioniraju u vizijama tzv. pametnih gradova. Paradigma pametnog grada u svijetu nije nova, već je u drugačijim oblicima i sintagmama bila prisutna i ranije, prije svega u najrazvijenijim zemljama svijeta, zasnivajući se na iskustvu održivog razvoja gradova kroz inovacije na polju industrije, obrazovanja, kulture, upravljanja gradovima i razvoj koncepta suvremenog građanstva. Nadovezuje se na gospodarsko-razvojne i ideološko-političke koncepte neoliberalnog kapitalizma koji se izmjenjuju od kraja 20. i početka 21. stoljeća, a izražavaju ih sintagme „informacijsko društvo“, „društvo znanja“, „kreativno društvo“. Zajedničko im je polazište da su informacije, znanje, inovacije i kreativnost (intelektualni kapital) generator gospodarskog rasta i društvenog napretka koji je zasnovan na digitalizaciji i najsuvremenijoj informacijsko-komunikacijskoj tehnologiji.

Od knjižnica se očekuje zauzimanje proaktivne uloge u urbanoj regeneraciji i transformaciji gradova te aktivan doprinos životu i gospodarskom rastu i održivom razvoju zajednica kojima služe. Da bi to ostvarile, knjižnice se u svojim uslugama usredotočuju na povezivanje građana sa zajednicom te njihovo osnaživanje u vještinama i kompetencijama koje se od njih očekuju, konkretno u razvoju pametnog društva. Prije svega radi se o vještinama i kompetencijama koje omogućuju snalaženje u digitalnom svijetu te potrebi ovladavanja sve složenijim kompetencijama u čitanju i pismenosti kao pretpostavkama cjeloživotnog učenja i uključivanja na tržište rada. ${ }^{3}$

Korištenjem metode benchmarking ${ }^{4} \mathrm{u}$ ovom se radu uspoređuje praksa hrvatskih knjižnica koje uglavnom nisu prepoznate kao razvojna sastavnica koncepata i strategija pametnih gradova s praksom knjižnica u Singapuru koje već nekoliko desetljeća prednjače u svijetu po svojoj uključenosti u nacionalne planove i strategije informacijskog društva, pa tako i u strategiju tzv. pametne nacije. Uvid u funkcioniranje hrvatskih i singapurskih knjižnica u prvom valu pandemije bolesti COVID-19 u prvoj polovici 2020. godine dobiven je analizom njihova komuniciranja s javnošću preko društvenih mreža kao dinamičnim i popularnim kanalom plasiranja informacija općenito. U slučaju knjižnica u Singapuru to su objave na Twitteru od veljače do rujna 2020., a u slučaju knjižnica u Hrvatskoj objave na Facebooku od ožujka do rujna 2020. na primjeru dviju narodnih knjižnica koje djeluju u hrvatskim vodećim pametnim gradovima - Gradske knjižnice Rijeka i Knjižnice i čitaonice „Fran Galović“ Koprivnica. Fokus je na njihovim aktivnostima tijekom zatvaranja fizičkih prostora različitih ustanova javne namjene u cijelo-

3 Leorke, D.; D. Wyatt. Public libraries in the smart city. London: Palgrave Macmillan, 2019. Str. 6.

4 Usp. Osmanagić Bedenik, N.; V. Ivezić. Benchmarking kao instrument suvremenog kontrolinga. // Zbornik Ekonomskog fakulteta u Zagrebu 4(2006), 331-346. [citirano: 2020-12-20]. Dostupno na: https://www.svijet-kvalitete.com/images/Web2014/04travanj2014/benchmarking.pdf. 
me svijetu, pa tako i knjižnica, kako bi se spriječili fizički kontakti među ljudima i širenje zaraze. Analiziraju se nastojanja tih knjižnica da zadrže svoj društveni utjecaj nastavljajući obavljati svoje informacijske, obrazovne, kulturne i socijalne temeljne uloge i zadaće u elektroničkom ili digitalnom obliku putem interneta.

Za primjer usporedbe $\mathrm{s}$ hrvatskim narodnim knjižnicama uzete su knjižnice $\mathrm{u}$ Singapuru zato što prednjače po kvaliteti poslovanja ne samo u jugoistočnoj Aziji nego i u međunarodnom knjižničarstvu. ${ }^{5}$ Te se knjižnice često uzimaju kao jedan od primjera renesanse investiranja u knjižnice zahvaljujući nacionalnim strategijama nacije znanja, a potom pametne nacije. ${ }^{6}$ Narodne knjižnice imaju značajno mjesto u urbanoj regeneraciji, urbanoj politici i arhitekturi javnih prostora u Singapuru. Dijele lokacije s ostalim prostorima javne namjene - prvenstveno trgovačkim centrima, kazalištima, javnim prometom, parkiralištima, restoranima. Svrha je takvog prostornog pozicioniranja potaknuti veće korištenje, socijalnu integraciju i koheziju. Također privlače pozornost međunarodne stručne javnosti kao predvodnice u globalnim promjenama zbog nađenih rješenja za najveće izazove 21 . stoljeća - u knjižničnoj arhitekturi, inovativnoj primjeni tehnologije u poslovanju, a prije svega kao medijatori u povezivanju lokalno-nacionalne dimenzije s globalnom. $^{7}$

Upravo zbog visoke tehnološke opremljenosti, kao i političke potpore uključivanju narodnih knjižnica u nacionalne strategije i planove gospodarskog i društvenog razvoja, singapurske su knjižnice već dva desetljeća, od početka 2000ih godina, predmetom tzv. knjižničarskog turizma - posjeta brojnih knjižničnih stručnjaka i znanstvenika iz mnogih zemalja svijeta, npr. iz Australije, Danske, Njemačke, Nizozemske, Velike Britanije, Norveške, Kine, Japana, Francuske i dr., koji su objavljivali radove, pa čak i knjige o singapurskim knjižnicama kao najmodernijima u svijetu. ${ }^{8}$

Jedan od razloga uzimanja Singapura za primjer dobre prakse u prilagođavanju knjižnica promjenama u digitalnom društvu jest i upoznavanje njihova rada tijekom posjeta autorice nekima od oglednih singapurskih knjižnica prilikom odr-

\footnotetext{
5 Usp. Internationalization of library and information science education in the Asia-Pacific region / edited by Alenzuela, Reysa, Kim, Heesop, Baylen, Danilo M. Hershey: IGI Global, 2020. Str. 115-116.

6 Henkel, M.; K.Scheibe; F. Zimmer; W. G. Stock. Singapore's library system and its place in a smart nation. // Proceedings of the International Conference on Library and Information Science 5, 1(2019), str. 9. [citirano: 2020-12-20]. Dostupno na: https://www.researchgate.net/publication/331071205_Singapore's_Library_System_and_its_Place_in_a_Smart_Nation

7 Mittermaier, B. Libraries in Singapore. Jülich: Forschungszentrum, Zentralbibliothek, 2007. Str. 17. [citirano: 2020-12-20]. Dostupno i na: https://juser.fz-juelich.de/record/58901/files/Bibliothek_17.pdf.

8 Usporedbe i primjera radi, hrvatski knjižničari tradicionalno uče o poslovanju od anglosaksonskih i nordijskih knjižnica, kojima su upravo singapurske knjižnice u posljednja dva desetljeća bile uzor i inspiracija za modernizaciju knjižničnih usluga.
} 
žavanja Svjetskog kongresa IFLA-e 2013. godine. Posjetila je Nacionalnu knjižnicu Singapura koja dijeli zgradu sa Središnjom narodnom knjižnicom, regionalnu knjižnicu Jurong, knjižnicu specijaliziranu za umjetnost The library@esplanade i knjižnicu u kojoj isključivo rade volonteri The library@chinatown. U okviru Središnje narodne knjižnice posjetila je Prvu zelenu dječju knjižnicu u svijetu opremljenu najnovijom digitalnom tehnologijom za edukaciju i igru za djecu na temu zaštite okoliša, održivog razvoja i ekologije.

\section{Uključenost knjižnica u Singapuru i Hrvatskoj u koncept pamet- nih gradova / pametnih društava / pametnih nacija}

\subsection{Pojam i određenje koncepta pametnih gradova}

Pametnim gradovima nazivaju se urbana naselja koja rade svjesne napore u usvajanju novih informacijsko-komunikacijskih tehnologija na strateški način te teže postizanju prosperiteta, učinkovitosti, djelotvornosti i kompetitivnosti na različitim društveno-ekonomskim razinama. ${ }^{9}$

Mnogo je definicija koje opisuju pojam ,pametni grad“, ali prema internetskim stranicama Europske komisije - Predstavništva u Hrvatskoj najjednostavnija je ona koja ga objašnjava kao viziju urbanog razvoja u kojemu se koristi digitalna i komunikacijska tehnologija (ICT) i internet stvari (IoT) kako bi se što bolje zadovoljile potrebe građana i unaprijedila učinkovitost gradskih usluga. ${ }^{10}$

Europski dokumenti i praksa, kao i definicija koju je postavio Europski parlament 2014. godine pod sintagmom ,pametni grad“ podrazumijevaju šest područja promoviranja održive strukture $i$ kvalitete života: pametna uprava, pametna ekonomija, pametna mobilnost, pametan okoliš, pametni građani i pametni način života (vidi sliku 1$).{ }^{11}$

Područje pametna uprava sadržava projekte koji javnu vlast čine transparentnom, a javne i socijalne usluge građanima dostupnima uz osnaživanje upravnih kapaciteta, dostupnost različitih baza podataka, stvaranje informacijskog servisa za komunikaciju s građanima, sudjelovanje građana u donošenju odluka te uključivanje građana u procese izrade strategija, planova i drugih dokumenata bitnih za lokalnu zajednicu. Područje pametna ekonomija podrazumijeva projekte povezane s unaprjeđenjem poslovanja inovacijama i jačanjem poduzetništva, ali i

\footnotetext{
9 Lamza-Maronić, M.; J. Glavaš; I. Mavrin. Urbani management: izazovi, upravljački trendovi i regeneracijske prakse za gradove. Osijek: Ekonomski fakultet Sveučilišta, 2019. Str. 37.

10 Budućnost u kojoj živimo: pametni gradovi. [citirano: 2020-12-20]. Dostupno na: https:// ec.europa.eu/croatia/future_we_live_in_smart_city_hr

11 What are smart cities? [citirano: 2020-12-20]. Dostupno na: https://ec.europa.eu/info/eu-regional-and-urban-development/topics/cities-and-urban-development/city-initiatives/smart-cities en.
} 
unaprjeđenjem odnosa prema potrošačima. Projekti u području pametna mobilnost doprinose održivom, inovativnom i sigurnom prometnom sustavu, a posebno sustavu javnog prijevoza. U području pametan okoliš podrazumijevaju se projekti za održivo upravljanje prirodnim resursima i zaštitu voda, mora, zraka te tla uvođenjem novih tehnoloških rješenja. Projekti iz područja pametni građani vezani su uz obrazovanje i specifične oblike edukacija za građane svih dobnih skupina s naglaskom na edukativnim programima kojima se razvijaju digitalne vještine građana te na cjeloživotno učenje koje potiče kreativnost, socijalni i etnički pluralizam, a što rezultira većim sudjelovanjem građana u lokalnoj zajednici doprinosom kvaliteti života. Područjem pametan način života obuhvaćeni su projekti vezani uz poboljšanje kvalitete života, prvenstveno unaprjeđenje zdravstvene kulture i kvalitete zdravlja svih starosnih skupina, kao i povećanje kvalitete života u drugim područjima poput stanovanja, obrazovanja, sigurnosti, socijalne inkluzije, kulture, sporta i rekreacije te održivog turizma. ${ }^{12}$

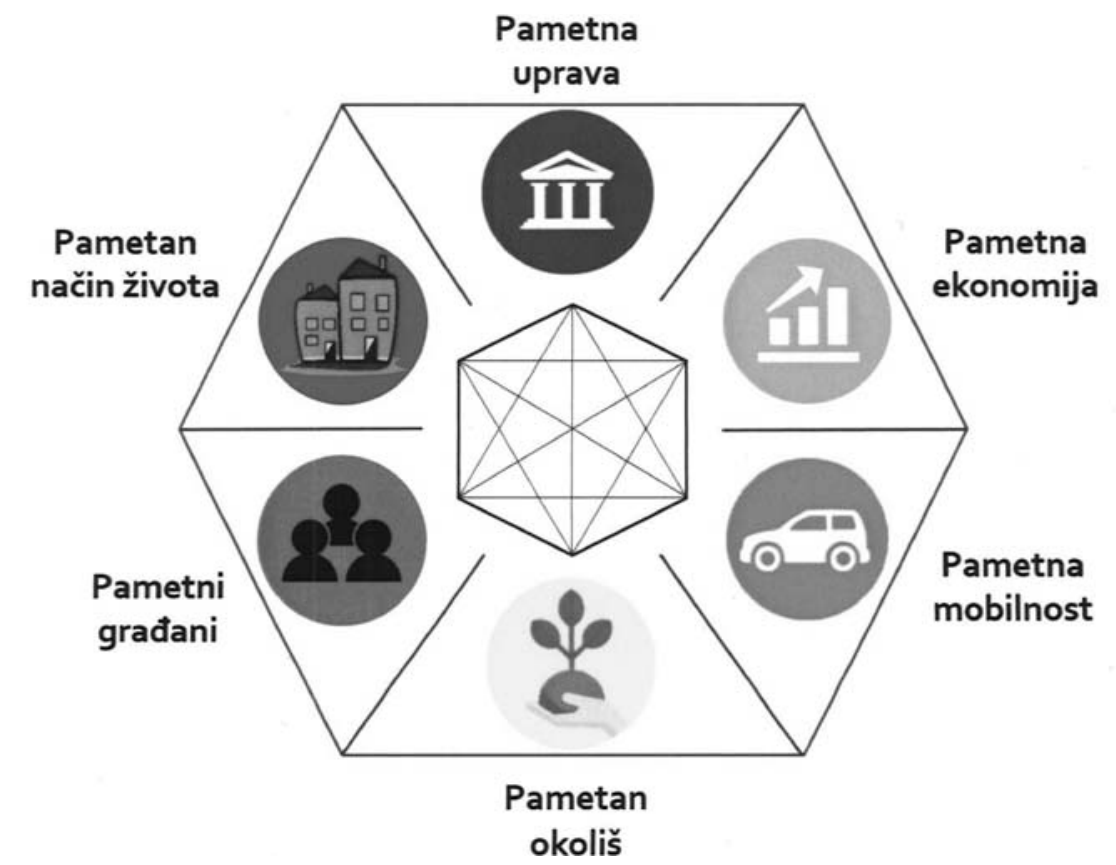

Slika 1. Shema područja primjene koncepta pametnog grada ${ }^{13}$

12 Prema: Globalni i europski okviri za razvoj pametnih gradova. // Strateški plan Rijeka Pametan grad za razdoblje 2019. - 2020. Str. 11-12. [citirano: 2020-01-25]. Dostupno na: https:// www.rijeka.hr/wp-content/uploads/2018/11/Strate\%C5\%A1ki-plan-Rijeka-Pametan-grad-zarazdoblje-2019.-2020.-godine.pdf.

13 Slika je preuzeta iz: Globalni i europski okviri za razvoj pametnih gradova. // Strateški plan Rijeka Pametan grad za razdoblje 2019.-2020. Str. 12. [citirano: 2020-01-25]. Dostupno na:https:// 


\subsection{Singapurske knjižnice kao predvodnice ideje uključivanja u kon- cept pametnih gradova}

Singapur, grad-država u jugoistočnoj Aziji, ima 5,68 milijuna stanovnika i veliku gustoću naseljenosti na površini od $719,1 \mathrm{~km}^{2}$. Neovisnost od britanske kolonijalne vlasti proglasio je 1963. godine, a potom i priključenje Malezijskoj Federaciji iz koje je istupio 1965. godine. Iste je godine proglašena Republika Singapur. ${ }^{14}$

Održavanje snažnih gospodarskih temelja jedna je od dugogodišnjih ključnih prednosti Singapura u međunarodnim razmjerima. Tu državu nazivaju jednim od četiriju ,azijskih tigrova“ (uz Tajvan, Južnu Koreju i Hong Kong) zbog snažnog rasta gospodarstva između 1960-ih i 1990-ih godina. Bilježi rezultate koji su znatno iznad svjetskog prosjeka u parametrima kao što su vlasnička prava, antikorupcijska praksa, fiskalna sloboda, poslovne slobode, slobode rada, monetarne slobode, trgovinska sloboda, investicijska sloboda i financijska sloboda. Singapur ima visoku nejednakost $u$ dohotku, ali vlada poduzima mjere za izgradnju uključivog društva. Svjetski je lider u upravljanju državom, a visoka kvaliteta upravljanja ima značajnu ulogu u razvoju zemlje i njezinu brzom gospodarskom napretku zasnovanom na informacijama, znanju i tehnologijama (a ne na prirodnim resursima kojima je taj grad-država siromašan). ${ }^{15} \mathrm{~S}$ druge strane, Singapur je i primjer provođenja autokratske i autoritarne vlasti i totalitarne političke kontrole nad svim segmentima društvenog života. Vlast se optužuje za ograničavanje političkih sloboda, slobode govora, cenzuru medija te konzervativan pristup prema populacijskom rastu (omogućuje doseljavanje imigrantima ako su spremni raditi za jeftiniju cijenu). Unatoč proklamiranom višestranačju, ista je politička stranka od 1959. godine na čelu Singapura, Stranka narodne akcije (People’s Action Party), a njezin lider do 1990., Lee Kuan Yew, uspostavio je autoritarni režim. Preokupacija države stvaranjem moderne i učinkovite nacije urodila je tzv. socijalnim inženjeringom koji se zasniva na multirasnom i multietničkom društvu i odgovornom ponašanju prema pojedinim društvenim skupinama. Neki od kritičara urbane regeneracije Singapura ukazuju na to da je program tzv. urbane sanacije doveo do zatiranja povijesne baštine i javnog prostora te stvaranja programiranih javnih prostora, između ostaloga socijalnih stambenih blokova kao izraza uvjerenja države da su modernitet i društveni red, isključenje „,nepoželjnog“ i promicanje nadzora i sigurnosti neophodni za državni gospodarski uspjeh. ${ }^{16}$

www.rijeka.hr/wp-content/uploads/2018/11/Strate\%C5\%A1ki-plan-Rijeka-Pametan-grad-zarazdoblje-2019.-2020.-godine.pdf.

14 Usp. Singapur. // Hrvatska enciklopedija, mrežno izdanje. Leksikografski zavod Miroslav Krleža, 2020. [citirano: 2020-12-20]. Dostupno na: http://www.enciklopedija.hr/Natuknica.aspx?ID=56119.

15 Usp. PESTLE analysis of Singapore, Mar 17, 2015. [citirano: 2020-12-20]. Dostupno na: https://pestleanalysis.com/pestle-analysis-of-singapore/.

16 Usp. Zhang, T.-T.; W. Tan. The good, the bad, and the utilitarian: Singapore's schizophrenic urbanism. // Urban transformation / edited by Ilka and Andreas Ruby. Zurich: Holein Foundation 
Singapur prednjači u svijetu ne samo po gospodarskoj razvijenosti nego i po provođenju koncepta pametnog grada kao temelja aktualnih nacionalnih razvojnih planova. Uzima se kao primjer kako upravljanjem resursima i korištenjem inovativnih modela urbanog planiranja i tehnologije u upravljanju gradovi mogu postati pametni ili održiviji. U međunarodnim se razmjerima navodi kao primjer uspješnog suočavanja s velikim izazovima u održivosti gradova, od prometnih gužvi i neučinkovitih zgrada do socijalne nejednakosti i stanovanja. ${ }^{17}$ Singapuru je 2016. dogine pripalo prvo mjesto na listi pametnih gradova u svijetu, kada je proglašen svjetskim liderom u primjeni politika i tehnologije pametne mobilnosti (gradskih fiksnih i mobilnih širokopojasnih usluga, gradskih aplikacija i politike otvorenih podataka). Na Svjetskom kongresu Smart City Expo izabran je za pametni grad 2018. godine zbog inicijativa i projekata u industriji urbanih inovacija i transformacija. ${ }^{18}$

Koncept pametne nacije ima svoj temelj u konceptu društva znanja i gospodarstva utemeljenog na znanju koji se počeo razvijati u Singapuru u prvoj polovici 1980-ih godina zasnivajući se na nacionalnom planu informatizacije. Početkom 1990-ih godina odbor sastavljen od 200 stručnjaka iz politike, industrije i znanosti razvio je viziju ,inteligentnog otoka“ (iN2015) po kojoj informacijsko-komunikacijska tehnologija treba prožimati svaki aspekt društva (kod kuće, na poslu i u slobodnom vremenu). ${ }^{19}$

Viziju Singapura u nacionalnim strateškim planovima koji se vezuju uz informatizaciju singapurskog društva prate i singapurske knjižnice svojim specijaliziranim planovima Library 2000 (1994.) i Library 2010 (2005.). Najnoviji plan Libraries of the Future (Knjižnice budućnosti), donesen 2015. godine, prati provedbu nacionalnog strateškog plana Smart Nation Singapore (Pametna nacija Singapur $)^{20}$, dokument koji se temelji na preoblikovanju Singapura kroz digitalnu ekonomiju, digitalnu vladu i digitalno društvo. ${ }^{21}$ Digitalna je transformacija

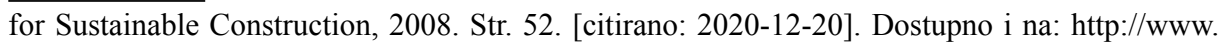
textbild.com/download/Tan_Zhang.pdf.

17 Usp. Sustainable cities: innovative urban planning in Singapore. [citirano: 2020-12-20]. Dostupno na: https://www.theguardian.com/sustainable-business/sustainable-cities-innovative-urban-planning-singapore.

18 Usp. Singapore named 'Global Smart City - 2016': mobility and technology drive Singapore smarts. [citirano: 2020-12-20]. Dostupno na: https://www.juniperresearch.com/press/press-releases/singapore-named-global-smart-city-2016.

19 Usp. Mittermaier, B. Nav. dj., str. 17.

20 Smart nation Singapore = Transforming Singapore through technology. [citirano: 2020-1220]. Dostupno na: https://www.smartnation.gov.sg/.

${ }^{21}$ Digitalna ekonomija podrazumijeva digitalizaciju industrije kako bi se povećala učinkovitost poslovanja i stvorila nova radna mjesta i mogućnosti za zapošljavanje. Digitalna vlada podrazumijeva integraciju usluga koje zadovoljavaju potrebe građana i potrebe poslovnih subjekata, potom jačanje integracije politike, poslovanja i tehnologije, povećanje digitalnih mogućnosti vlade za praćenje inovacija i zajedničko stvaranje s građanima i tvrtkama. Digitalno društvo 
sveobuhvatna jer su u njoj definirane uloge privatnog i javnog sektora, kao i svih stanovnika u realizaciji pametne nacije.

Knjižnice doprinose ostvarivanju vizije Singapura kao nacije znanja i pametne nacije realizacijom desetogodišnjeg strateškog razvojnog plana kojemu su u fokusu razvoj čitateljskih kompetencija, podupiranje lokalnih zajednica u kojima se uči i singapurske nacije kojoj je znanje pokretač gospodarskog i sveopćeg razvoja. U tom strateškom planu određena je osnovna zadaća knjižnica, a to je jačanje digitalnog društva kroz digitalno uključivanje građana. Prioritet je osigurati svim stanovnicima Singapura pristup tehnologiji koja može poboljšati svakodnevni život te opremiti ljude vještinama i znanjem za korištenje informacijske tehnologije na siguran i pouzdan način. ${ }^{22}$

Današnja mreža narodnih knjižnica izvrstan je model dobro vođenih i opremljenih knjižnica kao knjižničnih usluga i servisa s bogatim zbirkama, modernom tehnologijom i učinkovitim uslugama. ${ }^{23}$ Specifičnost organizacije jest u tome što je dio jedinstvenog sustava koji čine nacionalna knjižnica, nacionalni arhiv i 27 narodnih knjižnica. Imaju zajedničko upravljačko tijelo, nacionalni knjižnični odbor (engl. National Library Board of Singapore - NLB) koji koordinira poslovanje i provođenje zajedničkih programa i projekata. ${ }^{24}$ Osim toga, Singapur ima dobro razvijenu mrežu školskih knjižnica, a lider je u jugoistočnoj Aziji u visokoškolskim knjižnicama.

Povijest knjižničarstva u Singapuru započela je s britanskom kolonizacijom u 19. stoljeću. Razvoj singapurskih knjižnica slijedio je britanski kolonijalni model sve do plana modernizacije države od kraja 1950-ih godina. Tada je započelo planiranje i izgradnja satelitskih gradova u kojima se postupno osnivaju knjižnični ogranci kao podružnice Nacionalne knjižnice (otvorena 1960.) te je pokrenuta i usluga mobilne knjižnice. Od 1990-ih godina razvoj knjižnica usmjeren je na korištenje nove informacijsko-komunikacijske tehnologije i učinkovitije usluge za korisnike. Do 2002. godine u Singapuru je otvoreno devet knjižnica smještenih u trgovačkim centrima. U 2013. godini otvorena je u okviru Središnje narodne knjižnice prva dječja zelena knjižnica u svijetu, da bi transformacija singapurskih narodnih knjižnica u okviru strateškog plana Knjižnice budućnosti, koja se oslanja na nacionalni strateški plan Pametna nacija Singapur, rezultirala u razdoblju 2014. - 2019. s čak osam preuređenih ili ponovno otvorenih knjižnica.

Uz potporu digitalnoj inkluziji građana brojnim programima i projektima kojima se potiče i razvija digitalna pismenost svih dobnih i socio-profesionalnih sku-

podrazumijeva sveobuhvatnu transformaciju jer definira uloge privatnog i javnog sektora kao i svih stanovnika u realizaciji pametne nacije. Usp. Pillars of smart nation. [citirano: 2020-1220]. Dostupno na: https://www.smartnation.gov.sg/why-Smart-Nation/pillars-of-smart-nation\#sthash.1PviP2Nh.dpuf.

22 National Library Board Singapore. Annual reports. [citirano: 2020-12-20]. Dostupno na: https://www.nlb.gov.sg/WhoWeAre/CorporatePublications/AnnualReports.aspx.

${ }^{23}$ Usp. Leorke, D.; D. Wyatt. Nav. Dj.

24 National library board Singapore. [citirano: 2020-12-20]. Dostupno na: https://www.nlb.gov.sg/. 
pina korisnika, singapurske knjižnice uvode niz digitalnih inovacija u poslovanje knjižnice (npr. pametne kartice s digitalnim identitetom, e-plaćanje, platformu senzora i sigurnosti u kibernetičkom prostoru, nadziranje kretanja korisnika i građe, robotiku za automatizirane radnje sortiranja građe).

Glavne pravce potpore singapurskih narodnih knjižnica nacionalnim naporima na putu prema tzv. društvu znanja i tzv. pametnoj naciji Singapur sumiraju M. Henkel, K. Scheibe, F. Zimmer i W. G. Stock, ${ }^{25}$ a to su: snažna politička podrška knjižnicama i uređena pravna osnova njihova djelovanja; uspostavljanje koncepta knjižnica kao komunikacijskog središta, kao i trećeg mjesta pored kuće i radnog mjesta te lifestyle knjižnica koja uslugama prati stilove života (prije svega u integraciji tehnologije u svakodnevni život); sveprisutna ponuda izvora informacija i znanja (bilo gdje i bilo kada, u fizičkom i digitalnom obliku); osiguravanje prostora za učenje (primarna je funkcija knjižnica potpora cjeloživotnom učenju i obrazovanju); fizički položaj na mjestima koja se često posjećuju (najčešće uz trgovačke centre i prometne punktove); visokokvalitetne usluge, programi i projekti (dugoročne i kratkoročne aktivnosti); briga o kulturnoj baštini nacije; poticanje navika čitanja; poduke u digitalnoj pismenosti; poticanje sudjelovanja građana $\mathrm{u}$ radu knjižnica (internetskim društvenim medijima, pristupom design thinking u osmišljavanju novih usluga, njegovanjem mreže partnera na projektima, posebice volontera); rad sa sofisticiranom, najmodernijom tehnologijom i optimiziranje internih tijekova rada; izgradnja pripadnosti zajednici i nacionalnom identitetu Singapura.

\subsection{Uloga i utjecaj hrvatskih knjižnica na primjeru dvaju pametnih gradova}

I u Hrvatskoj je uočena važnost digitalne transformacije suvremenih gradova. Značajnu ulogu u tome ima inicijativa Europsko inovacijsko partnerstvo za pametne gradove $i$ zajednice čiji je cilj poboljšati život u europskim gradovima pomoću održivih integriranih rješenja. Predstavništvo Europske komisije u Hrvatskoj organizira projekt Pametni gradovi - gradovi budućnosti kojim želi potaknuti gradove u Hrvatskoj da više ulažu u unaprjeđenje infrastrukture i moderna tehnološka rješenja. ${ }^{26}$ Razvoj pametnih gradova i otoka posebno je istaknut u strateškom dokumentu Nacionalna razvojna strategija do 2030. godine. ${ }^{27}$

Međutim, Davor Škrlec, član Europskog parlamenta (2014. - 2019.) ukazuje na zaostajanje Hrvatske za nizom urbanih područja Europske unije u digitalnoj tran-

25 Henkel, M.; K.Scheibe; F. Zimmer; W. G. Stock. Nav. dj., str. 9.

26 Usp. Pametni gradovi u Hrvatskoj. [citirano: 2020-12-20]. Dostupno na: https://ec.europa.eu/ croatia/smart_city_in_Croatia_hr.

27 Usp. Nacrt prijedlog Nacionalne razvojne strategije Republike Hrvatske do 2030. godine. [citirano: 2020-12-20]. Dostupno na:https:/vlada.gov.hr/UserDocsImages/Vijesti/2020/11\%20 studeni/12\%20studenog/Nacrt\%20NRS\%202030\%20i\%20Dodaci-12112020.pdf 
sformaciji i primjeni tehnoloških rješenja u razvoju gradova, navodeći pri tome da Hrvatska „sitnim korakom ipak napreduje“. Ukazuje na to da se pametna rješenja hrvatskih gradova još uvijek ne temelje na holističkom pristupu koji bi se odnosio na sve segmente života. Od 128 gradova u Hrvatskoj, njih četrdeset provodi ili primjenjuje partikularna pametna rješenja u urbanom razvoju kao što su rasvjeta, elektronsko poslovanje uprave, energetika, javni prijevoz, zbrinjavanje otpada i sl. ${ }^{28}$

Za razliku od knjižnica u Singapuru, knjižnice u Hrvatskoj nemaju specijalizirane planove kojima bi pratile realizaciju nacionalnih strateških planova u informatizaciji i digitalnoj transformaciji. ${ }^{29}$ Međutim, praksa i dosadašnja bogata teorijska refleksija pokazuju da hrvatske narodne knjižnice, poput onih u Singapuru, svojim uslugama, programima i projektima djeluju na jačanju intelektualnog i socijalnog kapitala svojih zajednica, a što uključuje i jačanje digitalne pismenosti i digitalnih kompetencija građana te primjenu informacijsko-komunikacijske tehnologije u knjižničnom poslovanju. S obzirom na promoviranje održive strukture i kvalitete života u konceptu pametnog grada, hrvatske knjižnice najviše doprinose područjima koje određuju sintagme pametni građani i pametni način života.

Budući da Rijeka prednjači u tzv. pametnim rješenjima u upravljanju gradom u kategoriji hrvatskih velikih gradova, ${ }^{30}$ a Koprivnica u kategoriji srednjih hrvatskih gradova, ${ }^{31} \mathrm{u}$ ovoj komparaciji kriznog poslovanja u pandemiji bolesti COVID-19 Gradska knjižnica Rijeka uzeta je za primjer veće hrvatske knjižnice, a Knjižnica i čitaonica „Fran Galović“ Koprivnica kao primjer srednje velike hrvatske knjižnice u korištenju digitalne tehnologije u komunikaciji sa svojim korisnicima u pandemiji Covid-19. Usto, Gradska knjižnica Rijeka prednjači u Hrvatskoj po promišljanju pozicije narodnih knjižnica u konceptu pametnih gradova, kao i po novim tehnološkim rješenjima poput uključivanja u projekt gradske pametne

28 Usp. Škrlec, D. Pametni gradovi - budućnost ili stvarnost?. 2017. [citirano: 2020-12-20]. Dostupno na: https://www.davor-skrlec.eu/pametni-gradovi-buducnost-ili-stvarnost/.

${ }_{29}$ Za razliku od mnogih zemalja u svijetu u kojima su nacionalni strateški dokumenti u nadležnosti vlada, u Hrvatskoj knjižničarska zajednica inicira izradu strategija knjižnica koje ostaju u obliku prijedloga i nacrta. Hrvatsko knjižnično vijeće, savjetodavno tijelo pri Ministarstvu kulture i medija, usvojilo je dokument „Strategija razvoja hrvatskog knjižničarstva od 2016.-2021.“. Očekuje se da ovaj dokument budu ažuriran i kao strategija donesen nakon usvajanja Nacionalne razvojne strategije Republike Hrvatske do 2030. godine.

30 Grad Rijeka najbolji u Hrvatskoj u kategoriji Smart City / Pametni grad. [citirano: 2020-12-20]. Dostupno na: https://www.rijeka.hr/grad-rijeka-najbolji-u-hrvatskoj-u-kategoriji-smart-city-pametni-grad/.

31 Grad Koprivnica je prvi pametan grad u regiji s ISO certifikatom za mjerenje kvalitete života. [citirano: 2020-12-20]. Dostupno na: https://koprivnica.hr/novosti/grad-koprivnica-je-prvi-pametan-grad-u-regiji-s-iso-certifikatom-za-mjerenje-kvalitete-zivotathe-city-of-koprivnica-is-thefirst-smart-city-in-the-region-with-iso-certification-for-measurement-of-qual/; Gradu Koprivnici stiglo priznanje Smart City Award 2017. [citirano: 2020-12-20]. Dostupno na: https://koprivnica. $\mathrm{hr} /$ novosti/gradu-koprivnici-stiglo-priznanje-smart-city-award-2017; Knin , Jaska i Koprivnica od e-komunalnog redara i cesta do digitalne baze za investitore. [citirano: 2020-12-20]. Dostupno na: https://gradonacelnik.hr/smart-city/knin-jaska-i-koprivnica-od-e-komunalnog-redara-i-cesta-do-digitalne-baze-za-investitore/. 
kartice, prva je u Hrvatskoj oformila makerspace s 3D printerom te uvela elektroničke sadržaje dostupne online - časopis za djecu i časopis za odrasle. ${ }^{32}$ Također je dobila istaknuto mjesto u projektu Rijeka - Europski grad kulture 2020. s planiranom izgradnjom Središnje knjižnice i Dječje kuće kao novih objekata u kompleksu Benčić.

Knjižnica i čitaonica „Fran Galović“ Koprivnica, shodno financijskim i kadrovskim mogućnostima koja su skromnija u odnosu na Gradsku knjižnicu Rijeka, već tri desetljeća sustavno prati trendove u primjeni najnovije informacijsko-komunikacijske tehnologije i prednjači po implementaciji nekih rješenja u uslugama za korisnike (u posljednjih deset i više godina posebice u digitalizaciji lokalne zavičajne baštine i produkciji digitalnih slikovnica ${ }^{33}$ ), kao i u poslovanju.

Iako te dvije knjižnice sustavno unose nova digitalna tehnološka rješenja u poslovanje i rad s korisnicima, činjenica je da ta njihova nastojanja nemaju čvrstu i jasnu poziciju tzv. pametnih knjižnica u strategijama svojih tzv. pametnih gradova, kao što to uostalom u Hrvatskoj nemaju niti ostale sastavnice sektora kulture, obrazovanja, informiranja i socijalne djelatnosti. Kao što je već navedeno, izrada strategija pametnih gradova u Hrvatskoj je u začecima, nema holističkog pristupa za uključivanje svih područja života te je primjena digitalnih i informacijsko-tehnoloških rješenja uglavnom na razini gradske infrastrukture poput prometa, rasvjete, otpada i sl.

Budući da u Hrvatskoj još ne postoji praksa povezivanja nacionalnih i lokalnih strateških dokumenata o pametnim gradovima i pametnim društvima s ulogama knjižnica u njihovoj izgradnji, korisno je upoznati praksu sredina gdje su one već etablirane, konkretno na primjeru utjecaja pozicioniranosti singapurskih knjižnica u konceptu i strategiji pametne nacije na društveni utjecaj knjižnica u krizi prouzročenoj pandemijom bolesti COVID-19.

\section{Krizno komuniciranja singapurskih i hrvatskih narodnih knjižni- ca na društvenim mrežama tijekom pandemije bolesti COVID-19}

Pandemija bolesti COVID-19 stavila je gotovo istovremeno sve knjižnice u svijetu u specifičnu, u povijesti nezabilježenu, situaciju preispitivanja društvenih

32 Kristian Benić iz Gradske knjižnice Rijeka navodi neka obilježja ,,pametnih“ knjižnica, odnosno neka područja i ideje čijom implementacijom knjižnica postaje "pametna": Katalog po tvojoj mjeri - razvoj sustava pretraživanja po mjeri korisnika, Moja knjižnica, u mojem džepu - razvoj korisničkog čitalačkog identiteta, Sam posudi, sam vrati - razvoj slobode korištenja (kapacitete knjižničara, često ljudi s dva fakulteta, vrijedi osloboditi za sofisticiranije i kreativnije poslove od provlačenja knjige ispod bar-kod čitača), U knjižnici na Hogwartsu - razvoj virtualne stvarnosti, Zastrašujuća mogućnost izbora - razvoj sustava preporučivanja, Knjiga u IoT svijetu - razvoj sustava za praćenje i dijeljenje, Viber i posudba - razvoj novih sustava komunikacije, Knjižnica na ulici - razvoja sustava za život na ulici. Usp. Benić, K. „Pametna” knjižnica u „pametnom gradu”. // Magazin, 09. svibnja 2016. Dostupno na: https://gkr.hr/Magazin/Teme/Pametna-knjiznica-u-pametnom-gradu

33 Digitalne slikovnice „Mitska bića - digitalna priča“. [citirano: 2020-12-20]. Dostupno na: http://www.knjiznica-koprivnica.hr/knjiznica/defaultcont.asp?id=504\&n=2. 
uloga i zadaća zbog zatvaranja zgrada - fizičkih prostora s knjižničnim zbirkama, uslugama i programima koji ih definiraju kao društvena, komunikacijska okupljališta lokalnih sredina i mjesta socijalne integracije, inkluzije i kohezije. Međutim, zahvaljujući digitalnoj, elektroničkoj komponenti poslovanja i djelovanja koju su knjižnice u svijetu, na globalnoj razini, razvile s informacijsko-tehnološkim razvojem, uvođenjem interneta i informatizacijom svog poslovanja u posljednjim trima desetljećima, prilagodile su se kriznoj situaciji pandemije bolesti COVID-19 tako što su s fizičkim zatvaranjem naglasak stavile na virtualnu komponentu svog djelovanja. Kako su u tome uspijevale, može se zorno pratiti na primjeru knjižnica u Singapuru i u Hrvatskoj, zemljama potpuno različitog povijesno-kulturnog, zemljopisnog i političko-ideološkog položaja.

\subsection{Uvođenje epidemioloških mjera u knjižnice u Singapuru i Hrvatskoj}

Već na razini protokola po kojima su knjižnice u Singapuru i Hrvatskoj usklađivale svoje poslovanje tijekom pandemije bolesti COVID-19, uočavaju se sličnosti.

Prve informacije o uvođenju epidemioloških mjera u knjižnice u Singapuru zbog pandemije bolesti COVID-19 objavljene su na knjižničnoj društvenoj mreži Twitter 8. 2. 2020., ubrzo nakon kineske Nove godine. U knjižnicama se provode mjere predostrožnosti - korisnicima se na ulazu u knjižnice mjeri temperatura te skeniraju osobni dokumenti ne bi li se ušlo u trag putovanjima u Kinu iz koje se koronavirus proširio po cijelome svijetu (više od 90 \% stanovnika Singapura kineske je nacionalnosti). Pojačano se čiste i dezinficiraju knjižnični prostori. Objava 27. 3. 2020. govori o implementaciji mjera socijalne distance u knjižnične prostore. Otkazuju se svi planirani programi, zatvaraju pojedini dijelovi knjižnica, produžuje rok posudbe knjižnične građe od tri na šest tjedana, obavještava se korisnike da se ne zadržavaju u knjižnici, da što više ostaju kod kuće kako bi se smanjili fizički dolasci u knjižnice. Otkazuju se planirani programi kako bi se reducirala okupljanja. Do potpunog zatvaranja knjižnica u Singapuru dolazi 7. 4. 2020., što traje do 30. 6. 2020. Od 1. 7. 2020 . knjižnice se otvaraju korisnicima uz skraćeno radno vrijeme i samo za posuđivanje građe, uz dopušteno zadržavanje korisnika 30 minuta te uz apel na daljnje čitanje i učenje online. Od 1. 9. 2020. knjižnice se vraćaju na redovno radno vrijeme, ali uz ograničeno zadržavanje i samo za posuđivanje građe uz prethodnu najavu (tek 20. 10. 2020. omogućuje se korisnicima dulji boravak u knjižnicama uz prethodnu najavu (tri sata u Središnjoj narodnoj knjižnici i regionalnim knjižnicama, odnosno dva sata u ograncima).

U Hrvatskoj se preventivne zdravstvene mjere uvode u knjižnice više od mjesec dana kasnije nego u Singapuru s obzirom na globalni razvoj širenja zarazne bolesti i nacionalnu politiku ponašanja u situaciji pandemije te, shodno tome, odluke nacionalnog i lokalnih stožera civilne zaštite. Gradska knjižnica Rijeka prve informacije o epidemiološkim mjerama objavljuje na svojoj Facebook stranici 11. 
3. 2020. i 12. 3. 2020. Odjeli i ogranci rade prema redovnom radnom vremenu; međutim svi su čitaonički prostori zatvoreni, programi (do 40 sudionika) odvijaju se i dalje, ali ističe se potreba pridržavanja mjera opreza. Međutim, već su idući dan svi programi Gradske knjižnice Rijeka planirani do 15. 4. 2020. godine otkazani. Knjižnica skreće pozornost na sve mogućnosti korištenja usluga knjižnice „,na daljinu“, povećan je broj knjiga za posudbu od 4 na 6 , kako bi se smanjila potreba za češćim brojem posjeta odjelima i ograncima u nadolazećem razdoblju. Knjižnica poziva na komunikaciju koja ne uključuju fizički dolazak (elektronska pošta, telefon, društvene mreže, i sl.). Objavom od 13. 3. 2020. upućuje na mrežnu stranicu s relevantnim informacijama o koronavirusu https://www.koronavirus. hr/, da bi se već dan kasnije, 14. 3. 2020. zatvorili svi knjižnični prostori, što traje gotovo do kraja travnja.

Knjižnica i čitaonica „Fran Galović“ Koprivnica objavljuje prvu obavijest o uvođenju epidemioloških mjera 12. 3. 2020. - Odluku o privremenoj odgodi održavanja svih manifestacija u zatvorenim prostorima na području grada Koprivnice, dok knjižnica radi za korisnike normalno u svom redovnom radnom vremenu. Međutim, već 14. 3. 2020. knjižnica objavljuje da ne radi za korisnike sukladno Obavijesti o uvođenju pojačanih preventivnih mjera opreza na području grada Koprivnice. Upućuje poziv korisnicima da se pridržavaju novih knjižničnih pravila (posudba, zakasnina) i uputa Hrvatskog zavoda za javno zdravstvo o održavanju higijene i ponašanju prilikom društvenih kontakata.

Knjižnice u Hrvatskoj, pa tako i u Rijeci i Koprivnici, počinju postupno otvaranje vrata građanima od 27. 4. 2020. prema uputama Stožera civilne zaštite Republike Hrvatske i mjerama zaštite od koronavirusa koje je propisao Hrvatski zavod za javno zdravstvo - uz kratko zadržavanje u knjižnici, držanje fizičkog razmaka od dva metra radi sprječavanja širenja infekcije u prostorijama knjižnica, pranje ruku prije dolaska u knjižnicu kao jedne od glavnih mjera sprječavanja širenja virusa uz postavljena higijenska sredstva koja je potrebno koristiti na ulazu u knjižnicu. Knjige koje se vraćaju iz posudbe prolaze kroz proces čišćenja i vremenski odmak do daljnjeg puštanja u opticaj od 72 sata. ${ }^{34}$ Nošenje zaštitnih maski postalo je dijelom knjižnične svakodnevice.

Postupno otvaranje traje četiri mjeseca, sve do redovnog radnog vremena u rujnu, i nadalje uz poštivanje epidemioloških mjera i prema prilagođenim pravilima. ${ }^{35}$

\footnotetext{
34 Velike je dileme u knjižnicama u cijelome svijetu izazivalo pitanje duljine zadržavanja virusa na raznim površinama, pa i na papiru. Prema istraživanjima 78 sati najkraće je razdoblje za taj rizik, pa su se tome priklonile i hrvatske knjižnice.

35 Epidemiološka slika u Hrvatskoj i Singapuru te u svijetu u vrijeme pisanja izlaganja na 45. skupštini Hrvatskog knjižničarskog društva 7. 10. - 10. 10. 2020., na temelju kojega je nastao ovaj rad, ukazuje svojim brojkama na razinu učinkovitosti upravljanja zdravstvenom krizom na nacionalnim razinama, u Hrvatskoj i Singapuru tijekom pandemije COVID-19. Epidemiološka je slika 25. 9. 2020. bila sljedeća: Hrvatska - 223 novooboljelih u 24 sata, ukupan broj oboljelih 15 795, ukupan
} 


\subsection{Strategije kriznog komuniciranja na internetskim društvenim mre- žama}

Uvidom u komuniciranje s javnošću preko internetskih društvenih mreža u slučaju knjižnica u Singapuru na Twitteru od veljače do kraja rujna $2020 .^{36}$, a u Hrvatskoj na primjeru Gradske knjižnice Rijeka ${ }^{37}$ i Knjižnice i čitaonice „Fran Galović" Koprivnica na Facebooku $u^{38}$ od ožujka do kraja rujna došlo se do uvida da su knjižnice u Singapuru i Hrvatskoj koristile slične komunikacijske strategije u kriznoj situaciji, a u okviru obavljanja svojih informacijskih, obrazovnih, kulturnih i društvenih zadaća i uloga. Prva im je zajednička sličnost u prelasku isključivo na online komunikaciju s korisnicima zbog fizičke zatvorenosti knjižnica s fokusom na pružanje informacijsko-referalnih usluga. Oslanjaju se isključivo na digitalne sadržaje, izvore dostupne na mrežnim stranicama, društvenim mrežama i internetu općenito.

Strategije koje knjižnice pri tome koriste mogu se okvirno podijeliti na:

- pružanje socijalne i psihosocijalne podrške i potpore korisnicima

- upućivanje na postojeće vlastite elektroničke izvore i digitalnu građu

- upućivanje na tuđe elektroničke izvore i digitalnu građu

- stvaranje vlastitih novih digitalnih sadržaja (,proizvoda“) u kriznoj situaciji

- dijeljenje digitalnih resursa s drugim knjižnicama

- evaluacija vlastitih aktivnosti, postignuća i poslovanja za vrijeme pandemije bolesti COVID-19.

\subsubsection{Pružanje socijalne i psihosocijalne podrške, potpore i pomoći korisnicima}

Društveni angažman knjižnica dolazi do izražaja i u kriznoj situaciji uzrokovanoj pandemijom bolesti COVID-19. Konkretno, na početku pandemije u veljači 2020. knjižnice u Singapuru obavještavaju javnost o svojim donacijama knjiga radnicima imigrantima u karanteni u velikim stambenim zgradama - žarištima

broj umrlih 266; Singapur - 11 novooboljelih u 24 sata, ukupan broj oboljelih 57 665, smrtni slučajevi 27. Epidemiološka slika u vrijeme završetka pisanja ovog rada 20. 12. 2020. bila je: Hrvatska 1975 novooboljelih u 24 sata, ukupan broj oboljelih 194 962, broj umrlih 3 177; Singapur - 148 novooboljelih u posljednjih 14 dana; 58403 ukupan broj slučajeva; 29 umrlih; u svijetu broj oboljelih od COVID-19 bolesti (izvor ECDC) do 14. 12. 2020.: 71,5 mil., broj umrlih u svijetu (izvor ECDC) do 14. 12. 2020.:1 612 833. Usp. Koronavirus (COVID-19) - Singapur. [citirano: 2020-12-20]. Dostupno na: https://news.google.com/covid19/map?hl=hr\&mid=\%2Fm\%2F06t2t; Hrvatski zavod za javno zdravstvo. Koronavirus: najnoviji podatci. [citirano: 2020-12-20]. Dostupno na: https:// www.hzjz.hr/priopcenja-mediji/koronavirus-najnoviji-podatci/.

36 NLBSingapore@nlbsingapore. [citirano: 2020-09-15]. Dostupno na: https://witter.com/ nlbsingapore?lang=hr.

37 Gradska knjižnica Rijeka@GradskaKnjiznicaRijeka. [citirano: 2020-09-15]. Dostupno na: https://www.facebook.com/GradskaKnjiznicaRijeka/.

38 Knjižnica i čitaonica „Fran Galović“ Koprivnica@KnjiznicaFranGalovicKoprivnica. [citirano: 2020-09-15]. Dostupno na: https://www.facebook.com/KnjiznicaFranGalovicKoprivnica. 
korona virusa. U Hrvatskoj pak u ožujku 2020. Gradska knjižnica Rijeka poziva javnost na volontersko uključivanje u organiziranu dostavu hrane i lijekova za starije i potrebite, a koprivnička Knjižnica „Fran Galović“ uključuje se u akciju Hrvatskog studentskog zbora - posudbu 3D printera za izradu vizira za bolnice.

Knjižnice imaju i psihosocijalnu ulogu - preko objava na društvenim mrežama neprestano pozivaju na mirno i racionalno postupanje u danima koji nisu uobičajeni, šire optimizam i daju potporu u neizvjesnoj situaciji, a što se može objediniti formulacijom riječke knjižnice „Čitanjem i učenjem protiv korone!“‘.

\subsubsection{Informacijsko-referalne usluge knjižnica u službi informiranja, obrazova- nja, učenja, kulturnog razvoja i provođenja slobodnog vremena tijekom pandemije bolesti COVID-19}

Tijekom epidemije bolesti COVID-19 knjižnice u Hrvatskoj i Singapuru stavljaju u prvi plan svoje informacijsko-referalne zadaće, nastojeći zadržati ulogu informiranja, obrazovanja i kulture u nemogućnosti fizičke otvorenosti svojih prostora. Prvenstveno upućuju korisnike na postojeće vlastite digitalne resurse i preuzimanje tuđih.

\section{Upućivanje korisnika na vlastite postojeće elektroničke resurse}

Primarno upućujući na svoju mobilnu aplikaciju s besplatnom dostupnošću preko 500000 naslova $e$-građe singapurske knjižnice provode svoju misiju online u novim okolnostima izolacije ili lockdowna u trima inicijativama - olakšavanje učenja i čitanja; uvođenje dužeg roka posudbe $e$-građe; tjedno punjenje novim sadržajima online paketa za učenje na knjižničnoj mobilnoj aplikaciji (konkretno o pandemiji i javnom zdravstvu, meditaciji, suočavanju s neizvjesnim okolnostima, učinkovitim radom od kuće, novim hobijima).

Intenzivno promoviraju svoje digitalne usluge na Twitteru sloganima „Čitajte više kod kuće putem mobilne aplikacije!“, „Digitalne usluge dostupne 24/7“, „Mobilna aplikacija umjesto knjižničara“, „Građa na mobilnoj aplikaciji za koju niste znali da je besplatna za posudbu - $e$-knjige i audio knjige, $e$-časopisi i $e$-novine, online tečajevi - vrijedni stotine dolara“, „Budite ustrajni u čitanju i učenju - s nama online“.

Objavama na Twitteru preporučuju se elektronički izvori za unaprjeđenje rada od kuće, online pričaonice za djecu, online novine i časopisi, klasična glazba, slušanje audio knjiga, virtualne izložbe, tečajevi crtanja.

Gradska knjižnica Rijeka na početku zatvaranja fizičkih prostora također se oslanja na svoje postojeće, raspoložive digitalne resurse, prije svega na mobilnu aplikaciju ZaKi Book za posudbu e-knjiga sa 600 naslova knjiga na hrvatskom jeziku, inače proizvod Knjižnica grada Zagreba, s čijom je ponudom riječka knjižnica krenula neposredno prije karantene, u siječnju 2020. Brzo se prilagođava novim 
okolnostima tako da uvodi mogućnost online upisa i proceduru dobivanja PIN-a potrebnog za mobilnu $e$-knjige aplikaciju. Uz pandemiju, zbog snažnog potresa koji je 22. 3. 2020. pogodio Zagreb, koji se u blagoj varijanti osjetio i Rijeci te ispada mreže i struje, zabilježena je privremena nedostupnost mobilne aplikacije za $e$-knjige i online kataloge knjižnice s obzirom na to da se ključna infrastruktura nalazi u Zagrebu, no poteškoća je ubrzo uklonjena. Tijekom koronakrize, kada je potreba za digitalnim sadržajima bila posebno značajna, Američko je veleposlanstvo kroz program American Corner Rijeka podržalo nabavku e-knjiga koje je bilo moguće čitati kroz online/mobilnu aplikaciju ZaKi Book.

Osim e-knjiga, riječka knjižnica upućuje na korištenje ostalih svojih digitalnih resursa: online katalog, dva portala Magazin GKR (za odrasle) i Brickzine (za djecu) te platformu buduće Dječje kuće. Primjera radi, na Facebooku se daju poveznice na korisne članke iz starijih brojeva magazina, poput preporuka knjiga i časopisa, kao i korisnih savjeta tipa uradi sam, brige za zdravlje djece, zelenog kutka (npr. o balkonskim vrtovima), poslovnog kutka, psiholoških savjeta npr. o tome kako sačuvati psihičko zdravlje.

Knjižnica i čitaonica „Fran Galović“ Koprivnica također upućuje na postojeće vlastite digitalne resurse, koji su ipak skromniji u odnosu na riječku knjižnicu, a u objema navedenim hrvatskim knjižnicama daleko skromnijima u odnosu na knjižnice u Singapuru. Dostupni postojeći online izvori uključuju digitaliziranu zavičajnu kulturnu baštinu (stare lokalne novine, Galovićeva sabrana djela, razglednice i dr.) i digitalne slikovnice vlastite izvedbe. Od kraja 2019. koprivnička knjižnica započela je razvijanje vlastite mobilne aplikacije (e-katalog, događanja, digitalna iskaznica, produljenje, rezervacija), ali bez mogućnosti posudbe $e$-knjiga.

\section{Upućivanje korisnika na tuđe digitalne izvore}

Strategija upućivanja korisnika na tuđe online izvore snažan je alat koji koriste prvenstveno knjižnice u Hrvatskoj, zbog vlastitih siromašnih digitalnih resursa. Knjižnice u Singapuru također upućuju na vanjske izvore, poput časopisa i novina.

Gradska knjižnica Rijeka upućuje na virtualne muzeje, televizijske serije, filmove i glazbu s književnim predlošcima, besplatne $e$-knjige, online besplatne časopise i novine, priče na YouTubeu, predstave na Facebooku, televizijske serije „, čijem temelju su super knjige“ (,Predstave, filmovi, tutoriali, knjige... potpuni online cirkus - besplatno!“). Uz školu pred televizijom i slušanje mjera stožera također upućuje na online ponudu učenja i skreće pozornost na zanimljive online stranice servisa i tečajeva i kako korisno provesti slobodno vrijeme. Pri tome iskazuje posebnu brigu za djecu i mlade kao svoj i inače prepoznatljivi brand. Osim što upućuje na Međunarodnu dječju digitalnu knjižnicu s gotovo 5000 naslova, također upućuje na veliki izbor $e$-knjiga za posudbu potpuno besplatno preko The National Emergency Library, digitalne knjižnice, koja je nastala za vrijeme trajanja opasnosti od koronavirusa i zatvaranja svih fizičkih knjižnica te svima zainte- 
resiranima širom svijeta ponudila potpuno besplatno čak milijun i pol $e$-knjiga. Riječka knjižnica također upućuje na Internet Archive koji gradi digitalnu knjižnicu sa slobodnim pristupom istraživačima, povjesničarima i općoj populaciji, a cilj je omogućiti univerzalan pristup svom znanju. Isto tako, upućuje i na dostupnost digitalnih zbirki raznih knjižnica i institucija za razonodu ili za ozbiljna istraživanja.

Knjižnica i čitaonica „Fran Galović“ Koprivnica također upućuje na tuđe elektroničke izvore - interaktivnu slikovnicu COVIBOOK španjolske psihologinje Manuele Molina. Daje podršku učenicima u učenju na daljinu s korisnim i kvalitetnim edukativnim online izvorima za djecu predškolske i osnovnoškolske dobi, maturante, roditelje, stručne suradnike. Upućuje na popis virtualnih kulturnih sadržaja „U kazališta, muzeje, kina i na koncerte od kuće“ Knjižnice Filozofskog fakulteta u Zagrebu. Također upućuje na paket obrazovnih materijala o razlikovanju izvora informacija na internetu Fake or Fact (bit.ly/materijali-Fake-or-Fact) te na online lektirna djela i knjige za djecu za slobodno čitanje Nakladničke kuće Alfa.

\section{Stvaranje novih digitalnih i online sadržaja (,,proizvoda“) u kriznoj situaciji}

Stvaranje vlastitih novih digitalnih proizvoda u interakciji s korisnicima strategija je koju u pandemiji COVID-19 koriste i hrvatske i singapurske knjižnice.

Mreža koju čine ne samo narodne knjižnice nego i nacionalna knjižnica i nacionalni arhiv u Singapuru poziva korisnike da online dokumentiraju svoja iskustva u životu tijekom pandemije bolesti COVID-19 na posebnoj stranici https://go.gov. sg/documenting-covid19 uz sljedeći pozivni tekst:

„Od kada je počela pandemija bolesti COVID-19, brzo smo se prilagodili navikama čuvanja zdravlja. Naši javni prostori promijenili su se kao nikada ranije. Što se vama promijenilo? Recite nam kako ste se prilagodili i kako provodite vrijeme u ovim novim vremenima? ${ }^{* 39}$

Cilj je kampanje bio uključiti pojedince da svojim individualnim, neponovljivim pričama i svjedočanstvima doprinesu jasnijoj i punijoj slici o životu u kriznoj situaciji tijekom pandemije te angažirano sudjeluju u nacionalnim naporima dokumentiranja vremena. Time im se šalje poruka da su njihove priče jedinstvene koliko i zajedničke u izgradnji nacije Singapura. Akcija je rezultirala poslanim pričama o životu u svakodnevici u kriznoj situaciji, solidarnosti, komuniciranju putem Zooma, svadbama online, obavljanju poslova od kuće, blagovanju, učenju i poučavanju u digitalnom obliku itd.

Singapurske knjižnice u kolovozu 2020. postavljaju prvi knjižnični dispenzer, samoposlužni kiosk za podizanje online naručenih knjiga koji kombinira online rezervaciju knjiga s fizičkim podizanjem u kiosku postavljenom uz knjižnice.

39 NLBSingapore@nlbsingapore 10. lipnja 2020. [citirano: 2021-03-07]. Dostupno na: https:// twitter.com/nlbsingapore/status/1270687257192796160 
Gradska knjižnica Rijeka u travnju 2020. također uvodi novitete - projekt snimanja kratkih video preporuka knjižničara korisnicima za čitanje s poveznicama na Facebooku, kao i na $e$-katalog i posudbu $e$-knjige te čitanje putem aplikacije ZaKi Book. Zeleni kutak Gradske knjižnice Rijeka pripremio je za korisnike online kviz na temu ekologije. Riječki knjižničari napravili su i prototip vlastite originalne društvene stolne igre LIBERica, po njihovim riječima „prave zabave za vrijeme u kojem smo distancirani, zatvoreniji i previše pred ekranima“. Pozivaju korisnike da je testiraju i jave svoja mišljenja. Čitateljski klubovi riječke knjižnice sudjeluju u Noći knjige koja se odvijala online zbog opće karantene i tim povodom nastaju dva nova kluba tzv. Zoom ere, Moljci i Zoomeri, koji komuniciraju putem platforme Zoom.

Knjižnica i čitaonica „Fran Galović“ Koprivnica također stvara vlastite online sadržaje, odnosno seli redovne programe u virtualni svijet poput online radionice s Klubom „Latica“ za mlađe odrasle s intelektualnim teškoćama na temu „Ponašanje u medijima“, online razgovore knjižničara s književnicima povodom Noći knjige i pohranom knjižničnih video zapisa na platformu Watch te online anketom među Koprivničanima o preporukama knjiga koje su im obilježile život. Poziva roditelje na slanje videopreporuka svoje djece za čitanje drugoj djeci i sve to objavljuje poveznicama na društvenoj mreži. Knjižnica također predlaže novu igru ,pomoću emotikona sastavite naslov svoje omiljene knjige i filma i podijelite u komentarima“".40

\section{Dijeljenje preuzetih elektroničkih resursa između knjižnica}

Kada se govori o strategiji međusobnog ciljanog dijeljenja elektroničkih resursa među knjižnicama, treba spomenuti gestu solidarnosti Gradske knjižnice Požega s Knjižnicom i čitaonicom „Fran Galovićc" Koprivnica i svim knjižnicama u Hrvatskoj koje nisu imale mogućnost posudbe $e$-knjiga svojim članovima i to ustupanjem na tri mjeseca mobilne aplikacije ZaKi Book. Zanimljivo je istaknuti da je ta inicijativa omogućavanja dostupnosti $e$-knjiga u situaciji kada papirne knjige nisu bile dostupne za posudbu nije bila sustavno nacionalno rješenje, npr. potaknuto i koordinirano na razini Nacionalne i sveučilišne knjižnice u Zagrebu koja brine o funkcioniranju nacionalnog knjižničnog sustava, već se radilo o angažmanu jedne manje knjižnice koja je i sama nabavila aplikaciju za posudbu $e$-knjiga od najveće mreže narodnih knjižnica u Hrvatskoj, Knjižnica grada Zagreba.

\subsubsection{Evaluacija rada knjižnica u pandemiji}

Evaluacija i refleksija rada - aktivnosti, postignuća i rezultata poslovanja u kriznoj situaciji strategija je koju su osobito koristile singapurske knjižnice i to

40 Knjižnica i čitaonica „Fran Galović“ Koprivnica. 29. ožujka 2020. [citirano: 2021-03-07]. Dostupno na: https://www.facebook.com/page/174046106792/search/?q=pomo\%C4\%87u\%20 emotikona $\% 20$ sastavite $\% 20$ naslov\%20svoje $\% 20$ omiljene $\% 20 \mathrm{knjige} \% 20 \mathrm{i} \% 20$ filma $\% 20 \mathrm{i} \% 20$ podijelite $\% 20 u \% 20$ komentarima $\% 20$. 
sustavno plasirajući preko društvenih mreža informacije sa statističkim podacima kako o uspješnoj prethodnoj 2019. godini tako i o korištenju $e$-izvora u pandemiji bolesti COVID-19. Kao udarnu vijest objavljena je poveznica na vodeće nacionalne novine s izjavom singapurskog ministra komunikacija i informiranja o važnosti knjižnica kao fizičkih prostora u komunikaciji sa zajednicom i izgradnji pametne nacije Singapur. Objavljuju se i statistički podaci o korištenju $e$-izvora za vrijeme fizičkog zatvaranja knjižnica u odnosu na prethodnu 2019. godinu. Slike 2a i $2 \mathrm{~b}$ ukazuju na $150 \%$ povećanja posudbe $e$-knjiga i $70 \%$ povećanja posuditelja $e$-knjiga; s obzirom na profil posuditelja $e$-knjiga $67 \%\left(\begin{array}{l}103 \\ 020)\end{array}\right)$ su postojeći posuditelji, a $33 \%$ (50 660) su novi posuditelji, $56 \%$ postojećih članova (28 251) okrenulo se digitalnim resursima, a 44 \% (22 409) novi su članovi. Slika 3. ukazuje na 1,4 milijuna pregleda vlastite digitalne ponude - najviše digitalnih pričaonica, paketa za učenje, savjeta knjižničara i sudionika projekta Dokumentirajte COVID-19), a slika 4 na 29000 dnevnih prosječnih pregleda $e$-novina (slika 4).

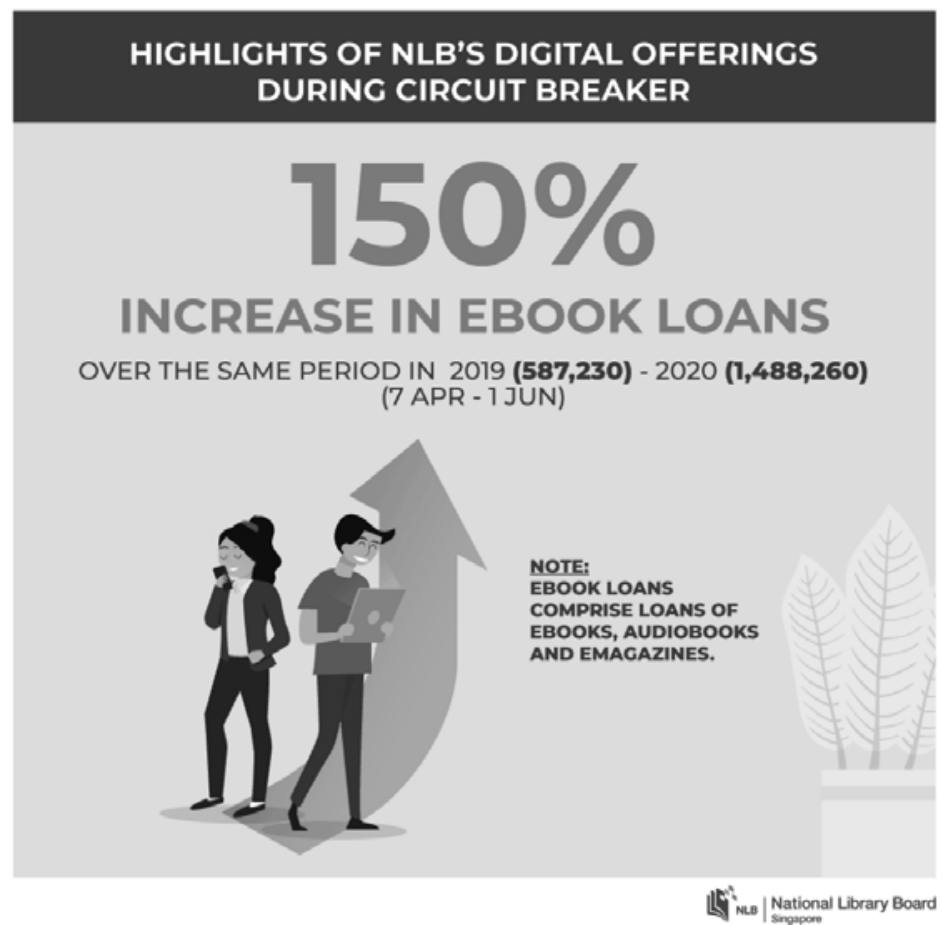

Slika $2 a$. Statistički podaci o povećanju posudbe $e$-knjiga i posuditelja $e$-knjiga ${ }^{41}$

${ }_{41}$ Usp. National Library Board, Singapore. // Facebook. [citirano: 2021-03-08]. Dostupno na: https://www.facebook.com/nlbsingapore/posts/did-you-catch-our-digital-offerings-during-thecircuit-breaker-we-hope-our-commu/10157287847940924/. 


\section{MORE ABOUT OUR EBOOK BORROWERS}

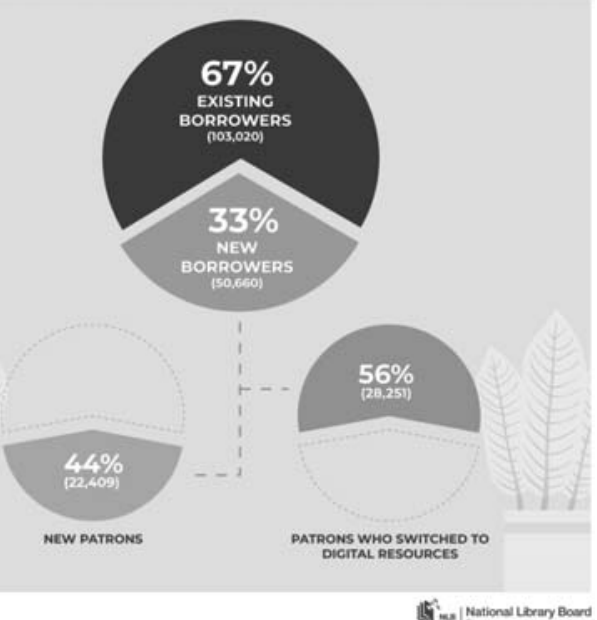

Slika $2 b$. Omjer postojećih i novih posuditelja digitalnih sadržaje tijekom fizičke zatvorenosti singapurskih narodnih knjižnica uslijed pandemije COVID-19 ${ }^{42}$

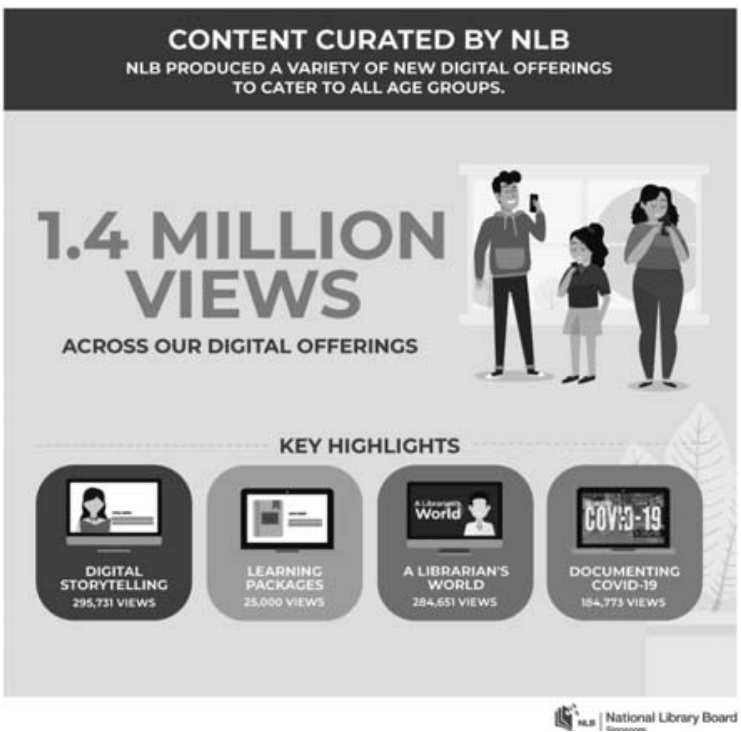

Slika 3. Statistički podaci singapurskih narodnih knjižnica o pregledima vlastite digitalne ponude za vrijeme pandemije bolesti COVID-19 (digitalne pričaonice, paketi za učenje, savjeti knjižničara, sudionici projekta Dokumentirajte COVID-19) ${ }^{43}$

\footnotetext{
42 Isto.

43 Isto.
} 


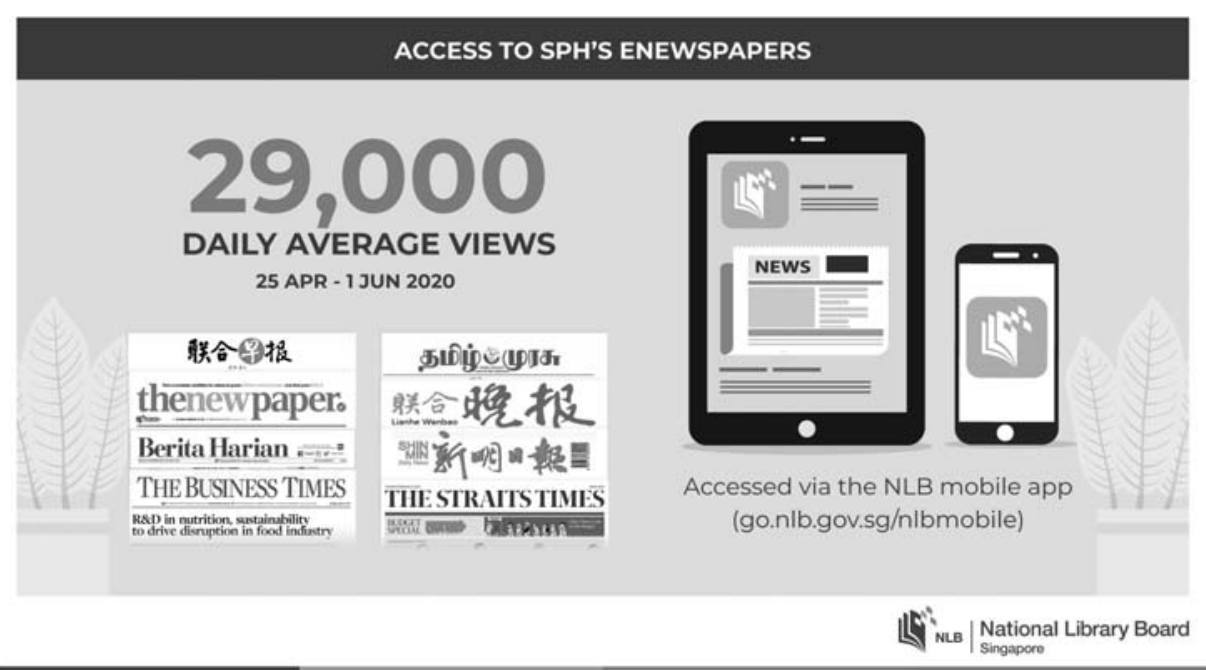

Slika 4. Statistički podaci o prosječnom dnevnom pregledu $e$-novina za vrijeme pandemije bolesti COVID-1944

Singapurske knjižnice također koriste društvenu mrežu Twitter za upućivanje online poziva na javne konzultacije o radu knjižnica 2021. - 2025. s ciljem prikupljanja prijedloga za nove usluge i programe.

Gradska knjižnica Rijeka kontinuirano na društvenim mrežama u stalnoj rubrici „Vijesti iz Benčića“ izvještava javnost o izvršenim građevinskim radovima na novim objektima Dječje kuće i Središnjeg odjela u novom art-kvartu Benčić. Također provodi online anketu o zadovoljstvu korisnika aplikacijom za posudbu $e$-knjige ZaKi Book te objavljuje periodičke osvrte u kojima se sumira učinjeno za vrijeme pandemije. ${ }^{45}$

Koprivnička knjižnica tijekom promatranog razdoblja plasirala je na Facebooku informacije o internim poslovima (npr. o selidbi oko $40000 \mathrm{knjiga}$ iz dislociranog spremišta na novu lokaciju, u kojoj prije fizičkog zatvaranja pomaže i bibliobus). U travnju obznanjuje dobivanje priznanja Američkog knjižničarskog društva za inovativne međunarodne knjižnične projekte za program „Mala škola korištenja pametnih telefona“. Dijeli informacije o postojećim programima za djecu (Knjige za bebe, Male knjižnice u pedijatrijskim ustanovama, dječjem čitateljskom klubu). Preko društvene mreže obilježava Dan dječje knjige, Svjetski

44 Isto.

45 U objavi na Facebooku Gradske knjižnice Rijeka od 26. travnja 2020. stoji: „Dječja kuća dobiva sve konkretnije konture, a sljedećih mjeseci ovdje ćete moći pratiti ulazak u finale realizacije izgradnje, proces uređivanja, zamisli o programima i jedinstvenoj energiji koja nas čeka po početku njenog pravog života“. 
dan Roma, Uskrs, Noć knjige, Dan planeta Zemlje kao znak održavanja rutine u digitalnom svijetu i podršku širenja optimizma.

\section{Zaključak}

U globalnoj izvanrednoj situaciji uzrokovanom pandemijom bolesti COVID-19 knjižnice u cijelome svijetu, pa tako i u Singapuru i u Hrvatskoj, doživljavaju poremećaje u poslovanju koji prvenstveno proizlaze iz nemogućnosti djelovanja knjižnica kao fizičkih prostora i prelaženja na online komunikaciju s korisnicima putem interneta.

U kriznoj situaciji knjižnice u svijetu, pa tako i one u Singapuru i odabranim primjerima iz Hrvatske, nastoje održati i zadržati svoj društveni utjecaj koji karakteriziraju uloge i zadaće koje imaju u suvremenom društvu kao mjesta kulture, informiranja, učenja i obrazovanja, komunikacije i susreta, stvaranja i eksperimentiranja, društvene kohezije, integracije i uključivosti.

Usporedba strategija koje knjižnice u Singapuru i Hrvatskoj koriste kako bi se prilagodile kriznoj situaciji s ciljem zadržavanja pozicija relevantnih središta svojih zajednica ukazuje na sličnosti i razlike.

Osnovne sličnosti, kao što pokazuje analiza strategija kriznog komuniciranja putem objava na društvenim mrežama promatranih knjižnica, uključuju: 1) pružanje socijalne i psihosocijalne podrške, potpore i pomoći korisnicima; 2) upućivanje na vlastite postojeće digitalne i elektroničke resurse; 3) stvaranje vlastitih novih digitalnih i elektroničkih resursa; 4) upućivanje na tuđe elektroničke i online izvore.

Sličnost im je i u tome što knjižnice i knjižničari postaju vodiči kroz digitalne sadržaje - izvore dostupne na vlastitim i tuđim mrežnim stranicama, društvenim mrežama i internetu.

Knjižnicama u svijetu, pa tako i onima u Hrvatskoj i Singapuru, također je zajednička brza prilagodba kriznoj situaciji zahvaljujući hibridnom karakteru, tj. digitalnoj i online komponenti poslovanja uz onaj fizički, koji intenzivno razvijaju unatrag tridesetak godina, posebice od 1990-ih godina 20. stoljeća s pojavom World Wide Weba i širokom primjenom interneta. U situaciji ugroze funkcioniranja knjižnice kao relevantnog fizičkog mjesta/prostora/zgrade i infrastrukture za obavljanje uloga i zadaća komunikacijskog središta lokalne sredine u realnom vremenu i prostoru, knjižnice u svijetu aktivirale su digitalnu komponentu svog poslovanja koja se iskazuje u stvaranju, posredovanju i distribuciji knjižnične građe u elektroničkom ili digitalnom obliku putem interneta.

Razlika u poslovanju hrvatskih i singapurskih knjižnica u pandemiji bolesti COVID-19 ukazuje na to da su knjižnice u Singapuru bile u prednosti u aktiviranju digitalne komponente svog poslovanja u pandemiji bolesti COVID-19 ti- 
jekom zatvaranja fizičkih prostora svojih knjižnica zbog veće i bolje tehnološke opremljenosti. Osim toga, bile su i društveno uključivije u odnosu na hrvatske knjižnice jer su pružale ravnopravnu ponudu elektroničkih i digitalnih sadržaja svim stanovnicima jednako. I prije pandemije svoje su korisnike mnogobrojnim programima pripremale za digitalno društvo na temelju jasno definirane društvene pozicije, uloga i zadaća u informacijskom društvu i strateškim dokumentima svoje vlade unutar koncepta i strategije pametne nacije.

Za razliku od singapurskog knjižničnog sustava, hrvatski knjižnični sustav u pandemiji bolesti COVID-19 nije djelovao jedinstveno u dijeljenju postojećih i stvaranju novih digitalnih resursa i mrežnih izvora, već su knjižnice bile upućene na vlastito snalaženje i povezivanje. To je rezultiralo nejednakošću u online dostupnosti elektroničkim sadržajima, prije svega u dostupnosti $e$-knjigama, a što je ovisilo o postojećoj ponudi i tehnološkoj razvijenosti pojedinih hrvatskih knjižnica. ${ }^{46}$ Činjenica da knjižnice nemaju političko-strateški sustavno dorađenu poziciju u (digitalnom) društvu, već ona ovisi o inicijativama pojedinih knjižnica, upućuje na neophodnost političke podrške pozicioniranju hrvatskih knjižnica u digitalnom društvu.

Međutim, pri prenašanju knjižničnih zadaća i uloga u virtualni svijet važan je kritički pogled kako knjižničara tako i društva na dominirajuću politiku tehnoloških inovacija i instrumentalizaciju stvaralaštva u kontekstu problematiziranja knjižnice kao prostorne infrastrukture i njene transformacije tijekom sve dubljeg prodora digitalizacije u sve sfere javnog i privatnog života.

U kontekstu sadašnjeg i budućeg utjecaja digitalnih tehnologija na razvoj knjižnica, uključujući i krizne situacije poput pandemije bolesti COVID-19, ali i uloge, vještina i znanja knjižničara za takav digitalni razvoj, treba u obzir uzeti i zalaganja za koncept knjižnica kao promotora tehnoloških promjena u opreci spram komercijalizacije interneta i postojanja digitalnog jaza između onih koji si mogu priuštiti pristup digitalnoj tehnologiji i onih koji ne mogu, čime se dovodi u pitanje inkluzivnost pametnog društva. Digitalni je jaz realna činjenica u svijetu u kojemu živimo. Stoga je važno da knjižnice, kao društveno dobro, budu ključni element pametnog društva te da propituju što mogu učiniti politički, kulturalno i društveno u promoviranju pravednosti i ljudskih vrijednosti kroz pametni ili smart životni stil, konkretno u integraciji tehnologije u naš svakodnevni život.

\footnotetext{
46 Umjesto jedinstvene nacionalne platforme za posuđivanje $e$-knjiga, što je uobičajena praksa i najrazvijenijih država u svijetu, u Hrvatskoj se trenutno paralelno razvijaju čak tri platforme za posudbu $e$-knjiga - Knjižnica grada Zagreba u suradnji s tvrtkom Viva info, knjižnice u Istarskoj županiji na čelu s Gradskom knjižnicom Pula u suradnji s nakladničkom kućom Beletrina iz Ljubljane i u začecima je ona Knjižnice i čitaonice „Fran Galović“" Koprivnica u suradnji s tvrtkom Metel.win.
} 


\section{LITERATURA}

Benić, K. „Pametna” knjižnica u „pametnom gradu”. // Magazin, 09. svibnja 2016. [citirano: 2020-12-20]. Dostupno na: https://gkr.hr/Magazin/Teme/Pametna-knjiznica-u-pametnom-gradu.

Budućnost u kojoj živimo: pametni gradovi. [citirano: 2020-12-20]. Dostupno na: https://ec.europa.eu/croatia/future_we_live_in_smart_city_hr.

Digitalne slikovnice „Mitska bića - digitalna priča“. [citirano: 2020-12-20]. Dostupno na: http://www.knjiznica-koprivnica.hr/knjiznica/defaultcont.asp?id=504\&n=2.

Globalni i europski okviri za razvoj pametnih gradova. // Strateški plan Rijeka Pametan grad za razdoblje 2019.-2020. [citirano: 2020-01-25]. Dostupno na: https:// www.rijeka.hr/wp-content/uploads/2018/11/Strate\%C5\%A1ki-plan-Rijeka-Pametan-grad-za-razdoblje-2019.-2020.-godine.pdf.

Grad Rijeka najbolji u Hrvatskoj u kategoriji Smart City / Pametni grad. [citirano: 202012-20]. Dostupno na: https://www.rijeka.hr/grad-rijeka-najbolji-u-hrvatskoj-u-kategoriji-smart-city-pametni-grad/.

Grad Koprivnica je prvi pametan grad u regiji s ISO certifikatom za mjerenje kvalitete života. [citirano: 2020-12-20]. Dostupno na: https://koprivnica.hr/novosti/grad-koprivnica-je-prvi-pametan-grad-u-regiji-s-iso-certifikatom-za-mjerenje-kvalitete-zivotathe-city-of-koprivnica-is-the-first-smart-city-in-the-region-with-iso-certification-for-measurement-of-qual/.

Gradska knjižnica Rijeka@GradskaKnjiznicaRijeka. [citirano: 2020-09-15]. Dostupno na: https://www.facebook.com/GradskaKnjiznicaRijeka/.

Gradu Koprivnici stiglo priznanje Smart City Award 2017. [citirano: 2020-12-20]. Dostupno na: https://koprivnica.hr/novosti/gradu-koprivnici-stiglo-priznanje-smart-city-award-2017.

Henkel, M.; K.Scheibe; F. Zimmer ; W. G. Stock. Singapore's library system and its place in a smart nation. // Proceedings of the International Conference on Library and Information Science 5, 1(2019), 9-47. [citirano: 2020-12-20]. Dostupno na: https:// www.researchgate.net/publication/331071205_Singapore's_Library_System_and its_Place_in_a_Smart_Nation.

Hrvatski zavod za javno zdravstvo. Koronavirus: najnoviji podatci. [citirano: 2020-1220]. Dostupno na: https://www.hzjz.hr/priopcenja-mediji/koronavirus-najnoviji-podatci/.

IFLA CPDWL Satellite Meeting 2019 Librarians and information professionals as (pro) motors of change: immersing, including and initiating digital transformation for smart societies. Zagreb, Croatia, 20 - 21 August 2019. [citirano: 2020-12-20]. Dostupno na: https://ifla.hkdrustvo.hr/. 
Internationalization of Library and Information Science Education in the Asia-Pacific Region / edited by Alenzuela, Reysa, Kim, Heesop, Baylen, Danilo M. Hershey: IGI Global, 2020.

Knin, Jaska i Koprivnica - od e-komunalnog redara i cesta do digitalne baze za investitore. [citirano: 2020-12-20]. Dostupno na: https://gradonacelnik.hr/smart-city/ knin-jaska-i-koprivnica-od-e-komunalnog-redara-i-cesta-do-digitalne-baze-za-investitore/.

Knjižnica i čitaonica „Fran Galović“ Koprivnica@KnjiznicaFranGalovicKoprivnica. [citirano: 2020-09-15]. Dostupno na: https://www.facebook.com/KnjiznicaFranGalovicKoprivnica.

Knjižnica i čitaonica „Fran Galović“ Koprivnica. 29. ožujka 2020. [citirano: 2021-0307]. Dostupno na: https://www.facebook.com/page/174046106792/search/?q=pomo\%C4\%87u\%20emotikona\%20sastavite\%20naslov\%20svoje $\% 20$ omiljene $\% 20$ knjige\%20i\%20filma\%20i\%20podijelite\%20u\%20komentarima\%20.

Koronavirus (COVID-19) - Singapur. [citirano: 2020-12-20]. Dostupno na: $\mathrm{https}$ ://news.google.com/covid19/map?hl=hr\&mid=\%2Fm\%2F06t2t.

Lamza-Maronić, M.; J. Glavaš; I. Mavrin. Urbani management: izazovi, upravljački trendovi i regeneracijske prakse za gradove. Osijek: Ekonomski fakultet Sveučilišta, 2019.

Leorke, D.; D. Wyatt. Public libraries in the smart city. London: Palgrave Macmillan, 2019.

Mikac, R. Kako Hrvatska upravlja krizama u kojima se našla? // Politička misao (31.03.2020.). [citirano: 2020-12-20]. Dostupno na: http://politickamisao.com/kako-hrvatska-upravlja-krizama-u-kojima-se-nasla/.

Mittermaier, B. Libraries in Singapore. Jülich: Forschungszentrum, Zentralbibliothek, 2007. [citirano: 2020-12-20]. Dostupno i na: https://juser.fz-juelich.de/record/58901/ files/Bibliothek_17.pdf.

Nacrt prijedlog Nacionalne razvojne strategije Republike Hrvatske do 2030. godine. [citirano: 2020-12-20]. Dostupno na: https://vlada.gov.hr/UserDocsImages/Vijesti/2020/11\%20studeni/12\%20studenog/Nacrt\%20NRS\%202030\%20i\%20Dodaci-12112020.pdf.

National Library Board, Singapore. // Facebook. [citirano: 2021-03-08]. Dostupno na: https://www.facebook.com/nlbsingapore/posts/did-you-catch-our-digital-offeringsduring-the-circuit-breaker-we-hope-our-commu/10157287847940924/.

National Library Board Singapore. Annual reports. [citirano: 2020-12-20]. Dostupno na: https://www.nlb.gov.sg/WhoWeAre/CorporatePublications/AnnualReports.aspx.

NLBSingapore@nlbsingapore. [citirano: 2020-09-15]. Dostupno na: https:/twitter. com/nlbsingapore?lang $=\mathrm{hr}$. 
NLBSingapore@nlbsingapore 2. srp 2020. [citirano: 2021-01-24]. Dostupno na: https:// twitter.com/nlbsingapore/status/1278614447540645888NLBSingapore@nlbsingapore.

Osmanagić Bedenik, N.; V. Ivezić. Benchmarking kao instrument suvremenog kontrolinga. // Zbornik Ekonomskog fakulteta u Zagrebu 4(2006), 331-346. [citirano: 202012-20]. Dostupno na: https://www.svijet-kvalitete.com/images/Web2014/04travanj2014/benchmarking.pdf.

Pametni gradovi u Hrvatskoj. [citirano: 2020-12-20]. Dostupno na: https://ec.europa.eu/croatia/smart_city_in_Croatia_hr.

PESTLE analysis of Singapore, Mar 17, 2015. [citirano: 2020-12-20]. Dostupno na: https://pestleanalysis.com/pestle-analysis-of-singapore/.

Pillars of smart nation. [citirano: 2020-12-20]. Dostupno na: https://www.smartnation. gov.sg/why-Smart-Nation/pillars-of-smart-nation\#sthash.1PviP2Nh.dpuf.

Singapur. // Hrvatska enciklopedija, mrežno izdanje. Leksikografski zavod Miroslav Krleža, 2020. [citirano: 2020-12-20]. Dostupno na: http://www.enciklopedija.hr/Natuknica.aspx?ID=56119.

Singapore Named 'Global Smart City - 2016': Mobility and Technology Drive Singapore Smarts. [citirano: 2020-12-20]. Dostupno na: https://www.juniperresearch. $\mathrm{com} /$ press/press-releases/singapore-named-global-smart-city-2016.

Smart nation Singapore $=$ Transforming Singapore Through Technology. [citirano: 2020-12-20]. Dostupno na: https://www.smartnation.gov.sg/.

Strateški plan Rijeka Pametan grad za razdoblje 2019. - 2020. godine. [citirano: 202012-20]. Dostupno na: https://www.rijeka.hr/wp-content/uploads/2018/11/Strate\%C5\%A1ki-plan-Rijeka-Pametan-grad-za-razdoblje-2019.-2020.-godine.pdf.

Sustainable cities: innovative urban planning in Singapore. [citirano: 2020-12-20]. Dostupno na: https://www.theguardian.com/sustainable-business/sustainable-cities-innovative-urban-planning-singapore.

Škrlec, D. Pametni gradovi - budućnost ili stvarnost? (2017). [citirano: 2020-12-20]. Dostupno na: https://www.davor-skrlec.eu/pametni-gradovi-buducnost-ili-stvarnost/.

What are smart cities? [citirano: 2020-12-20]. Dostupno na: https://ec.europa.eu/info/ eu-regional-and-urban-development/topics/cities-and-urban-development/city-initiatives/smart-cities_en.

Zhang, T.-T.; W. The good, the bad, and the utilitarian: Singapore's schizophrenic urbanism. // Urban transformation / edited by Ilka and Andreas Ruby. Zurich: Holein Foundation for Sustainable Construction, 2008. [citirano: 2020-12-20]. Dostupno i na: http://www.textbild.com/download/Tan_Zhang.pdf. 